\title{
Glomerular filtration rate measurement and estimation in chronic kidney disease
}

\author{
George J. Schwartz $\cdot$ Susan L. Furth
}

Received: 8 July 2006 /Revised: 29 August 2006 /Accepted: 11 September 2006 /Published online: 10 January 2007

(C) IPNA 2007

\begin{abstract}
Glomerular filtration rate (GFR) assesses kidney function. GFR is measured by renal clearance techniques; inulin clearance is the gold standard but is not easily measured. Thus, other methods to determine GFR have been utilized. Endogenous creatinine clearance $(\mathrm{CrCl})$ is the most widely used, but creatinine secretion falsely elevates GFR. Cimetidine inhibits creatinine secretion, such that $\mathrm{CrCl}$ equals GFR, provided there are no difficulties with bladder emptying. Estimation of GFR from serum creatinine (e.g. Schwartz formula) is useful clinically; however, such formulae have not been updated for enzymatic creatinine autoanalyzers. Cystatin $\mathrm{C}$, a small protein, is produced at a relatively constant rate and is reabsorbed in the proximal tubule. Cystatin $\mathrm{C}$ may be more sensitive than creatinine in detecting a reduction in GFR, but further studies are needed to prove this. Single injection (plasma) clearance techniques are the most precise measures of GFR. Iohexol is an exogenous marker that is comparable to inulin and ${ }^{51} \mathrm{Cr}$-EDTA and can be measured by high-performance liquid chromatography (HPLC). Our pilot and the Chronic Kidney Disease in Children (CKiD) North American studies show that iohexol can accurately measure GFR using a four-point plasma disappearance curve national studies show that iohexol can accurately measure GFR using a four-point plasma disappearance curve $(10,30,120$, and $300 \mathrm{~min}$ ) or, in most cases, a two-point disappearance time (120 and $300 \mathrm{~min}$ ).
\end{abstract}

\section{G. J. Schwartz $(\bowtie)$}

Pediatric Nephrology, University of Rochester Medical Center, Box 777, 601 Elmwood Avenue,

Rochester, NY 14642, USA

e-mail: George_Schwartz@urmc.rochester.edu

\section{S. L. Furth}

Department of Pediatrics, Johns Hopkins Children's Center, Baltimore, MD, USA
Keywords Iohexol · HPLC · KDOQI P Plasma clearance · Cimetidine $\cdot$ Creatinine clearance $\cdot$ Cystatin $\mathrm{C}$

\section{Introduction}

Chronic kidney disease (CKD) encompasses a continuum of renal impairment characterized by decreasing glomerular filtration rate (GFR). GFR is the most useful measurement of kidney function. Other functions of the kidney, i.e., production of erythropoietin, activation of vitamin $\mathrm{D}$, and ion and solute transport also decline as GFR declines. GFR represents the volume of plasma ultrafiltrate presented to the nephrons per unit time in the process of urine formation. GFR is measured indirectly through the concept of clearance, which is defined as the equivalent volume of plasma from which a substance would have to be totally removed to account for its rate of excretion in urine per unit of time. Clearance is calculated by dividing the excretion rate of a substance by its plasma concentration $\left(\mathrm{C}_{\mathrm{x}}=\mathrm{U}_{\mathrm{x}} \mathrm{V} /\right.$ $\mathrm{P}_{\mathrm{x}}$ ) where $\mathrm{U}_{\mathrm{x}}$ and $\mathrm{P}_{\mathrm{x}}$ are urine and plasma concentrations, respectively, of substance $\mathrm{x}$, and $\mathrm{V}$ is urine flow rate. When the substance is freely filtered, and not protein bound, and is not reabsorbed, secreted or metabolized by the kidney, then $\mathrm{C}_{\mathrm{x}}=\mathrm{GFR} . \mathrm{C}_{\mathrm{x}}$ is expressed as milliliters per minute, and is usually normalized to a standard $1.73 \mathrm{~m}^{2}$ idealized adult body surface area $\left(\mathrm{C}_{\mathrm{x}}\right.$ in milliliters per minute per $\left.1.73 \mathrm{~m}^{2}\right)$ by the factor $1.73 / \mathrm{BSA}$, where BSA is the body surface area (in square meters) of the examined subject. Normal values of GFR for infants, children, and young adults are presented in Table 1 in milliliters per minute per $1.73 \mathrm{~m}^{2}$.

Although some authors have questioned the value of normalizing GFR to body surface area, normalization allows easy comparison to standard adult values for GFR [1-3]. The most direct standard of reference would be 
Table 1 Glomerular filtration rate in healthy infants, children, and young adults as assessed by inulin clearance

\begin{tabular}{lll}
\hline Age (gender) & $\begin{array}{l}\text { Mean GFR } \pm \mathrm{SD} \\
(\mathrm{ml} / \mathrm{min} \text { per } \\
\left.1.73 \mathrm{~m}^{2}\right)\end{array}$ \\
& \\
\hline
\end{tabular}

\begin{tabular}{lll}
\hline Pre-term babies & & \\
1-3 days & $14.0 \pm 5$ & {$[76]$} \\
1-7 days & $18.7 \pm 5.5$ & {$[77]$} \\
4-8 days & $44.3 \pm 9.3$ & {$[78]$} \\
3-13 days & $47.8 \pm 10.7$ & {$[79]$} \\
8-14 days & $35.4 \pm 13.4$ & {$[77]$} \\
1.5-4 months & $67.4 \pm 16.6$ & {$[79]$} \\
Term babies & & \\
1-3 days & $20.8 \pm 5.0$ & {$[77]$} \\
3-4 days & $39.0 \pm 15.1$ & {$[80]$} \\
4-14 days & $36.8 \pm 7.2$ & {$[81]$} \\
6-14 days & $54.6 \pm 7.6$ & {$[82]$} \\
15-19 days & $46.9 \pm 12.5$ & {$[77]$} \\
1-3 months & $85.3 \pm 35.1$ & {$[80]$} \\
$0-3$ months & $60.4 \pm 17.4$ & {$[83]$} \\
4-6 months & $87.4 \pm 22.3$ & {$[83]$} \\
$7-12$ months & $96.2 \pm 12.2$ & {$[83]$} \\
$1-2$ years & $105.2 \pm 17.3$ & {$[83]$} \\
Children & & \\
3-4 years & $111.2 \pm 18.5$ & {$[83]$} \\
5-6 years & $114.1 \pm 18.6$ & {$[83]$} \\
$7-8$ years & $111.3 \pm 18.3$ & {$[83]$} \\
9-10 years & $110.0 \pm 21.6$ & {$[83]$} \\
11-12 years & $116.4 \pm 18.9$ & {$[83]$} \\
13-15 years & $117.2 \pm 16.1$ & {$[83]$} \\
2.7-11.6 years & $127.1 \pm 13.5$ & {$[80]$} \\
$9-12$ years & $116.6 \pm 18.1$ & \\
Young adults & & \\
$16.2-34$ years & $112 \pm 13$ & \\
\hline & & \\
\hline
\end{tabular}

kidney weight, but this is not available in clinical practice. However, kidney weight bears a constant relation to body surface area in animals and humans, indicating that the surface area basis of comparison is the most useful [1].

Measurement of GFR is the best clinical test for estimation of functioning renal mass. Knowledge of GFR enables the clinician to prescribe fluids and solutes, determine the progression of kidney disease, predict the development of end-stage renal disease (ESRD), and appropriately dose medications excreted by the kidney.

\section{Physiology of glomerular filtration}

Normal kidneys contain approximately two million glomerular capillary units [4-6]. Each glomerulus consists of a tuft of capillaries interposed between the afferent and efferent arterioles. The glomerular capillary wall is made up of three layers: the fenestrated endothelial cell, the glomerular basement membrane (GBM), and the epithelial cell. The epithelial cells, podocytes, are attached to the GBM by discrete foot processes. The slits between the foot processes are covered by a thin membrane called the slit diaphragm $[4,7,8]$. The GBM is derived from material produced by endothelial and epithelial cells, including type IV collagen, laminin, nidogen, and heparan sulfate proteoglycans. Laminin and nidogen form a tight complex to promote cell adhesion. The anionic heparan sulfate proteoglycans may contribute to the electrical charge barrier to the filtration of anionic macromolecules $[4,8]$.

One of the primary functions of the glomerulus is to allow the filtration of small solutes, such as sodium and urea and water, while restricting the passage of larger molecules. This permits the kidney to maintain homeostasis by excreting the nitrogenous waste derived from dietary intake, while preserving the essential larger plasma protein molecules. Solutes up to the size of inulin (mol. wt. 5,200) are freely filtered, whereas myoglobin (mol. wt. 17,000) is filtered less completely than inulin, and albumin (mol. wt. 69,000 ) is filtered only to a minor degree. Filtration is also limited for ions or drugs that are bound to albumin.

GFR is determined by two factors: the filtration rate in each nephron, also referred to as single nephron GFR (SNGFR), and the number of filtering nephrons. Each normal kidney in humans is endowed with approximately one million nephrons at birth. Blood entering through the afferent arteriole goes into the glomerular capillary tuft and exits through the efferent arteriole. Along the glomerular capillary tuft a portion of the glomerular plasma is ultrafiltered into Bowman's space, which, after being processed by renal tubules and collecting ducts, leads to the formation of urine. Fluid movement across the glomerulus is governed by Starling's forces, being proportional to the permeability of the glomerular capillary wall and to the balance between hydraulic and oncotic pressure gradients.

\section{Assessment of glomerular filtration rate}

Since the total kidney GFR equals the sum of the SNGFRs in each of the functioning nephrons, the total GFR can be used as an index of functioning renal mass. Following nephron loss, compensatory changes in surviving nephrons are commonly observed in clinical practice. This leads to a lesser loss of total renal function than anticipated by the extent of anatomic damage. In fact, the earliest nephron losses are likely to be invisible due to functional compensation, which would bring GFR back into the normal range. For example, a loss of half the functioning nephrons leads to a decrease in GFR of only $20-30 \%$, rather than the anticipated $50 \%$ [9]. In most patients with early chronic kidney disease (CKD), the fluid and electrolyte balance is 
well maintained, and even the urinalysis may be normal. The decline in GFR may, therefore, be the earliest and only clinical sign of renal disease. Serial monitoring of GFR can be used to estimate severity and to monitor the course of CKD.

\section{Inulin clearance}

Inulin, which has a mean molecular radius of $1.5 \mathrm{~nm}$ and a molecular weight of approximately 5,200, is considered an ideal marker and the gold standard for measuring GFR. Inulin is freely filtered, is not protein bound, is not reabsorbed, does not affect kidney function, and is neither secreted nor metabolized by the kidney. When injected intravenously, inulin clearance equals GFR $\left(\mathrm{C}_{\mathrm{x}}=\mathrm{C}_{\mathrm{In}}=\mathrm{GFR}\right)$ [10].

The classic (standard) inulin clearance requires an intravenous priming dose of inulin, followed by a constant infusion to establish a steady-state inulin plasma concentration [11]. After an equilibration for $\sim 45 \mathrm{~min}$, serial urine samples are collected every 10-20 min through an indwelling bladder catheter. Insertion of an indwelling urinary catheter might not be possible or justifiable in current clinical practice; urine is obtained voluntarily in such cases every 20-30 min, as dictated by the urge of the patient to urinate. High urine flow is maintained throughout the test by providing an initial oral water load of 500 $800 \mathrm{ml} / \mathrm{m}^{2}$ and replacing urinary water loss with oral intake of water (milliliter-per-milliliter) [10]. Continuous infusion clearances obviate the need for urine collection, as once a steady state is achieved, the infusion rate is essentially equal to the excretion rate [12].

The use of inulin clearances has a number of limitations. First, some children may not be toilet trained and are unable to provide accurate collections of timed urine. Second, urologic problems are common causes of CKD in infants and young children [13], and many of these children have significant vesicoureteral reflux, neurogenic bladders, or bladder dyssynergia. The collection of timed urine in such patients is difficult and fraught with error. Third, technical difficulties encountered in performing inulin infusions, and reaching a steady state of inulin distribution, are common. Lastly, inulin is not currently readily available. These problems have rendered the standard inulin clearance to be impracticable in children.

\section{Endogenous creatinine clearance and the use of cimetidine}

Because of the difficulties with administering and measuring inulin, standard endogenous creatinine clearances have been used to estimate GFR. Creatinine results from the enzymatic degradation of creatine synthesized in skeletal muscle. Urinary excretion of creatinine is therefore a product of muscle catabolism and hence an index of muscle mass [14]. In the steady state, serum creatinine also correlates well with muscle mass $[15,16]$. Creatinine has a molecular mass of $113 \mathrm{Da}$ and is eliminated exclusively by the kidneys via glomerular filtration and, to a lesser extent, by tubular secretion. Endogenous creatinine clearance provides an acceptable measurement of GFR for clinical purposes and is calculated by the following equation:

$\mathrm{C}_{\mathrm{cr}}=\mathrm{U}_{\mathrm{cr}} \mathrm{V} / \mathrm{S}_{\mathrm{cr}}$,

where $\mathrm{C}_{\mathrm{cr}}$ is creatinine clearance, $\mathrm{U}_{\mathrm{cr}}$ is urine creatinine concentration, $\mathrm{V}$ is flow rate of urine in milliliters per minute, and $\mathrm{S}_{\mathrm{cr}}$ is serum creatinine. The creatinine clearance is normalized to body surface area (BSA) by being multiplied by the factor 1.73 BSA in square meters. The relative constancy of creatinine production and its urinary excretion in the steady state helps one analyze for completeness of the collection (creatinine excretion per kilogram body weight). Urinary creatinine excretion should generally be approximately $20 \mathrm{mg} / \mathrm{kg}$ per day in children over 3 years of age (slightly higher in pubertal adolescent boys) [14, 17-19], and values less than this indicate incomplete urine collection or loss of some urine. Largely because of difficulties in obtaining accurate urine collections (both under- and over-collection of $24 \mathrm{~h}$ urine can occur), recent Kidney Disease Outcomes Quality Initiative (KDOQI) guidelines state that "measurement of creatinine clearance using timed urine collections does not improve the estimate of GFR over that provided by prediction equations" [20]. Daily variations in urinary creatinine excretion for a given subject can result in standard deviations of $10-15 \%[19,21]$.

When creatinine clearance is performed by $24 \mathrm{~h}$ urine collection, the child is asked to empty the bladder in the morning ( 7 A.M.) of the day of the test; the urine is discarded, and the time is noted as the start of the collection. All urine voided in the next $24 \mathrm{~h}$ is collected in the container as part of this collection. At the end of $24 \mathrm{~h}$ (7 A.M. the next day) the bladder is emptied and the last void is deposited in the container as the final part of the collection. The volume of urine is noted accurately, and the urine is analyzed for creatinine concentration. Blood (for serum creatinine) is drawn once during this time period.

Averaging several short clearance periods $(\sim 30 \mathrm{~min})$ after water loading tends to minimize errors in urine collection and improve supervision of the study [22]. Large variations in urine creatinine excretion indicate significant vesicoureteral reflux or problems in bladder emptying that might warrant bladder catheterization to improve accuracy. In addition creatinine concentration is affected by dietary intake of meat, exercise, pyrexia and a variety of sub- 
stances. Patients are frequently asked to ingest a lowprotein diet prior to the creatinine clearance study, as ingesting a protein load can change GFR. More importantly, it is well known that creatinine is secreted by the renal tubules, and this secretory component accounts for $\sim 10 \%$ of the urinary creatinine excretion in healthy individuals [15]. Whereas urinary creatinine contributed by tubular secretion does not normally exceed $10 \%$, this fraction rises greatly during chronic renal insufficiency, and creatinine clearance may greatly exceed GFR, particularly at low levels of GFR [11, 15].

The administration of cimetidine to patients with renal disease causes a decrease in tubular creatinine secretion, resulting in a creatinine clearance that approximates the level of true GFR [23]. The protocol modified by Hellerstein and colleagues used cimetidine for 3 days at a dose of $20 \mathrm{mg} / \mathrm{kg}$ in two divided doses (maximum 1,600 $\mathrm{mg}$ per day and a sliding scale dose reduction for decreased GFR) [24]. After a final dose of half the daily dose and an oral load of 7-8 $\mathrm{ml} / \mathrm{kg}$ of fluids, urine is collected for approximately $2 \mathrm{~h}$ under supervision [25]. Alternatively, urinary clearance during four supervised periods of $\sim 30 \mathrm{~min}$, with replacement of urine output, can be measured. While the cimetidine protocol is a convenient, inexpensive procedure for estimating GFR, failure to document bladder emptying by ultrasound, lack of toilet training, and the presence of vesicoureteral reflux, neurogenic bladders, and bladder dyssynergias can cause inaccuracies in the results because of problems in urine collection.

\section{Estimated GFR based on serum creatinine}

The close relationship between creatinine clearance and GFR on the one hand, and creatinine production and muscle mass on the other, along with the difficulties of collecting urine, have led to the concept of estimating GFR from serum creatinine and some parameter of body habitus, as detailed by Schwartz et al. [26]:

$\mathrm{eGFR}=\mathrm{kL} / \mathrm{S}_{\mathrm{cr}}$,

where eGFR is estimated GFR in milliliters per minute per 1.73 square meters, $\mathrm{k}$ is a constant determined empirically by Schwartz and associates [27], L is height in centimeters, and $\mathrm{S}_{\mathrm{cr}}$ is serum creatinine in milligrams per deciliter. This formula is also based on the relationship that $\mathrm{C}_{\mathrm{cr}}$ is reciprocally proportional to the serum creatinine. A dimensional analysis of $\mathrm{k}$ (milligrams creatinine $/ 100 \mathrm{~min} \times \mathrm{cm} \times$ $1.73 \mathrm{~m}^{2}$ ) indicates that $\mathrm{k}$ is equal to $\mathrm{U}_{\mathrm{Cr}} \mathrm{V} / \mathrm{L}$, which is directly related to urinary creatinine excretion, which is, in turn, proportional to lean body mass [18, 27].

The value of $\mathrm{k}$ is 0.45 for term infants during the first year of life [18], 0.55 for children and adolescent girls [26], and 0.7 for adolescent boys [17]. Such a formula generally provides a good estimate of GFR ( $\sim 0.9$ ) when compared with creatinine and inulin clearance data $[24,26]$. Interestingly, at high values of GFR, the variation between inulin clearance and GFR estimated by the Schwartz formula was about $20 \%$, but it was much smaller at lower levels of GFR $[24,26]$. It should be noted that these constants were generated from creatinine values measured using a modification of the Technicon autoanalyzer method, which relies on a Jaffe chromogen reaction to quantify creatinine. Recently, Zappitelli et al. have published revisions of the Schwartz formula relating eGFR to serum creatinine determined enzymatically, using the creatinase methods available in more modern autoanalyzers [28]. The enzymatic creatinine values generally run $10-20 \%$ lower than those measured by the Jaffe method [29], and so one would anticipate that " $\mathrm{k}$ " values should be comparably smaller than those listed above. In the Zappitelli report, the " $\mathrm{k}$ " value in the Schwartz equation decreased from 0.55 to 0.47 for children and adolescent girls [28]. In the Chronic Kidney Disease in Children (CKiD) pilot study [30], and in the baseline CKiD cohort of children aged 1 to 16 years with mild to moderate CKD, estimated GFR using the Schwartz formula and enzymatic creatinine overestimated the GFR determined by the plasma disappearance of iohexol by approximately $12 \mathrm{ml} / \mathrm{min}$ per $1.73 \mathrm{~m}^{2}$. Further evaluation of baseline and longitudinal data on simultaneously obtained serum creatinine, other laboratory data, body habitus parameters and iohexol-based GFR will lead to refinements of GFR-estimating equations for children in the CKiD study.

Counahan and colleagues [31] generated a similar formula using "near-true" creatinine determinations in children of varying ages, and the resulting $\mathrm{k}$ was 0.43 . The lower $\mathrm{k}$ value may reflect the lower value of creatinine after removal of non-creatinine chromogen with an ion exchange resin. Indeed, this $\mathrm{k}$ value is approximately $20 \%$ smaller than that of the $\mathrm{k}$ obtained from the modified Technicon autoanalyzer, which is in keeping with the expected reduction in apparent serum creatinine concentration using the "true" method.

The estimated GFR formulae have some limitations and should not be used for patients with severe obesity or malnourishment or limb amputation, in whom body height may not accurately reflect muscle mass [27]. Additionally, these GFR estimate formulae are not accurate when GFR is rapidly changing, such as in critically ill children or in acute renal failure [32].

The Cockcroft-Gault equation [33], which is used to estimate GFR in adults, may also be useful in children over 12 years of age [34].

$\mathrm{e}^{\prime} \mathrm{GFR}=(140-$ age $)($ body weight in $\mathrm{kg}) /\left(72 \times \mathrm{S}_{\mathrm{cr}}\right)$

where e'GFR is the estimated GFR using the CockcroftGault equation in males; in females a correction factor of 
0.85 is used. Whereas there is good overall agreement with standard inulin clearances in children aged 12 years and older, Cockcroft-Gault estimates are very different from inulin clearances in younger patients. The formula for adults, generated by the Modification of Diet in Renal Disease (MDRD) group, is not useful in children [34].

\section{Cystatin C}

Cystatin $\mathrm{C}$ is a non-glycosylated $13 \mathrm{kDa}$ basic protein that acts as a cysteine proteinase inhibitor and is produced at a relatively constant rate. This constancy is apparently not influenced by the presence of inflammatory conditions, muscle mass, gender, body composition, and age (after 12 months) $[35,36]$. Blood cystatin $\mathrm{C}$ level is approximately $1 \mathrm{mg} / 1$ in healthy individuals [37]. Cystatin $\mathrm{C}$ is catabolized and almost completely reabsorbed by renal proximal tubular cells, so that little is excreted in the urine [38] and cannot be used to calculate a clearance GFR. Interindividual variation of cystatin $\mathrm{C}$ level is significantly less $(25 \%)$ than that of creatinine (93\%) [39]. The upper limit of the population reference interval for cystatin $\mathrm{C}$ is seldom more than 3-4 SD from the mean value of any healthy individual (compared with $13 \mathrm{SD}$ for creatinine). These findings suggest that cystatin $\mathrm{C}$ is potentially a better marker than creatinine is for detecting impaired renal function.

From a number of clinical studies of cystatin C [40], including one in healthy children [35], two key findings are evident. First, the concentration of serum cystatin $\mathrm{C}$ correlated better with directly measured values for GFR than did serum creatinine. Second, subtle decrements in GFR are more readily detected by the determination of serum cystatin $\mathrm{C}$ than by creatinine concentration [40]. Thus, while cystatin $\mathrm{C}$ is not a conventional marker of GFR, reciprocal values of serum cystatin C levels are reasonably well correlated with GFR in adults [41, 42] and in children [29, 43-45].

Some studies have suggested that the serum concentration of cystatin $\mathrm{C}$ might be superior to serum creatinine in distinguishing normal from abnormal GFR [46]. However, because it is metabolized and not excreted, cystatin $\mathrm{C}$ cannot be used to measure GFR by standard urinary clearance techniques [40]. Nevertheless, serum cystatin can be used to estimate GFR in milliliters per minute per 1.73 square meters according to the following formula [47]: $\log _{10}(\mathrm{GFR})=1.962+\left[1.123 \times \log _{10}(1 /\right.$ cysC $\left.)\right]$, where cysC is cystatin C. Additional formulae using both cystatin $\mathrm{C}$ and creatinine to estimate GFR have recently been reported [28].

Other studies have shown that plasma cystatin $\mathrm{C}$ is slightly better than plasma creatinine in diagnosing renal insufficiency but is less sensitive than creatinine clearance or eGFR (from $\mathrm{k} \times \mathrm{L} / \mathrm{Pcr}$ ) [48]. Moreover, cystatin C levels may underestimate GFR in renal transplant patients [49]. More recent studies have shown that factors other than renal function, such as C-reactive protein (CRP) and smoking status, may influence serum cystatin $\mathrm{C}$ concentrations, so that caution must be used when one is interpreting serum cystatin $\mathrm{C}$ levels as a measure of renal function [50]. The findings of cystatin $\mathrm{C}$ in the urine during glomerular and tubular injury also casts some doubt on the ability of serum cystatin $\mathrm{C}$ to accurately estimate GFR [51, 52].

\section{Single-injection clearance techniques}

The renal clearance of a substance that is not metabolically produced or degraded, and that is excreted from the body completely or almost completely in the urine, can be calculated from compartmental analysis by monitoring its rate of disappearance from the plasma following a single intravenous injection [53]. The mathematical model for the disappearance curve is an open two-compartment system. The GFR marker is injected in the first compartment, equilibrates with the second compartment, and is excreted from the first compartment by glomerular filtration. Initially, the plasma concentration falls rapidly but at a progressively diminishing rate, as there is diffusion of the marker in its distribution volume as well as its renal excretion. Thereafter, the slope of the decline of plasma concentration predominately reflects its renal excretion rate. This latter decrease occurs at the same exponential rate in the compartments wherein it is distributed.

The plasma disappearance curve can be resolved into two exponential decay curves by plotting the logarithm of the plasma concentration as a function of time and applying the technique of curve stripping (Fig. 1). The terminal slow (renal) portion of the curve (line A) is extrapolated back to zero time, and its $\mathrm{Y}$ intercept (A) and slope $(\alpha)$ are determined. When the values along line $\mathrm{A}$ are subtracted from the original curve, a second linear function (line $\mathrm{B}$ ) is obtained. Its $\mathrm{Y}$ intercept (B) and slope $(\beta)$ are also noted. The clearance of the substance (GFR) can be calculated as [53]:

$\mathrm{GFR}=$ Dose $/[(\exp (\mathrm{A}) / \alpha+(\exp (\mathrm{B}) / \beta)] \times 1.73 / \mathrm{BSA}$.

where Dose is the administered amount of GFR marker, and GFR is normalized to $1.73 \mathrm{~m}^{2}$ by being multiplied by 1.73 BSA. Because all the dosed marker is excreted in the urine, this equation essentially resembles the familiar $\mathrm{GFR}=\mathrm{UV} / \mathrm{P}$. To obtain an accurate plasma disappearance curve, one requires several blood samples. Extension of sampling to $5 \mathrm{~h}$ is essential to assure accuracy at low levels of GFR.

Excellent and comparable results may also be obtained using the one-compartment (renal curve) model, by which 
Fig. 1 Disappearance of iohexol as a function of time after injection into the blood. The natural logarithm of the iohexol concentration is plotted against the time in minutes. The curve can be stripped into two components, the slow or renal curve with slope $\alpha$ and intercept A. When those points are subtracted from the initial curve, a straight line with a steeper slope $\beta$ defines the fast or distribution curve with intercept B

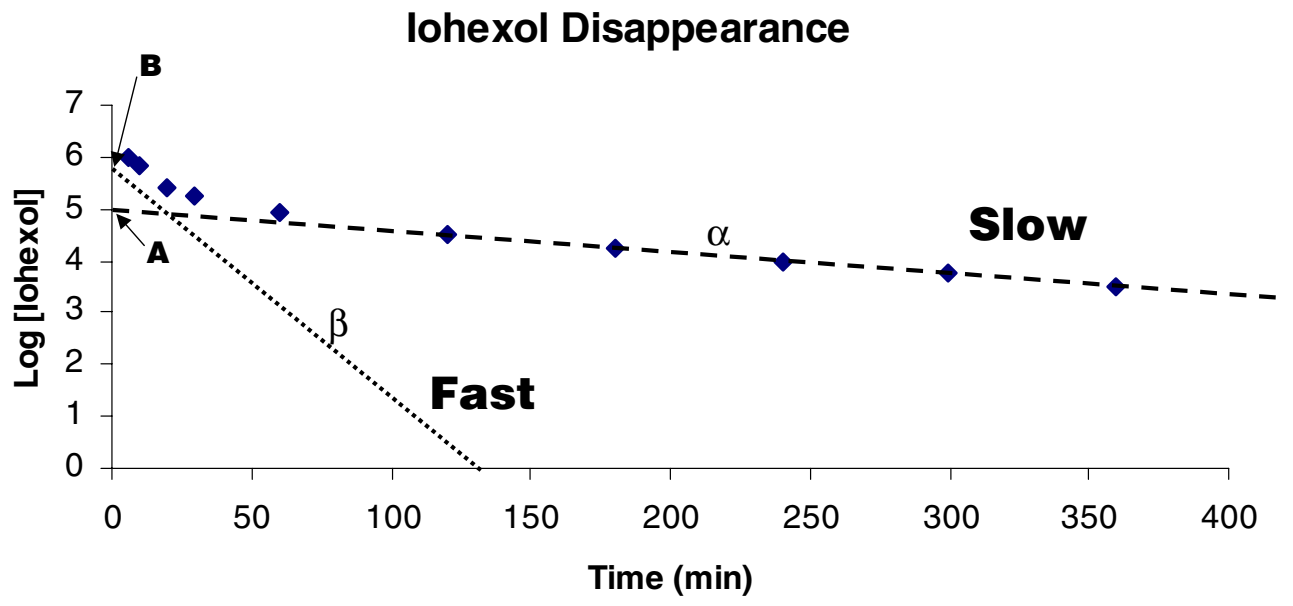

samples are obtained 2-5 $\mathrm{h}$ after injection, as described by Brochner-Mortensen [54]:

$\mathrm{GFR}=\mathrm{C} 1 \times \mathrm{GFR}(\mathrm{A})+\mathrm{C} 2 \times[\mathrm{GFR}(\mathrm{A})]^{2}$,

where GFR $(\mathrm{A})=\operatorname{Dose} /[\exp (\mathrm{A}) / \alpha]$, and $\mathrm{C} 1=0.9908$ and $\mathrm{C} 2=-0.001218$, as generated by Brochner-Mortensen in adults by comparing with plasma disappearance curves for ${ }^{51} \mathrm{Cr}$-EDTA. Similar constants have been generated for children by Brochner-Mortensen [55], using comparable methodology $(\mathrm{C} 1=1.01 ; \mathrm{C} 2=-0.0017)$, and recently by us in the CKiD pilot study [30] $(\mathrm{C} 1=0.9950 ; \mathrm{C} 2=-0.001159)$. Whether or not the one-compartment model is accurate in patients with large amounts of edema and ascites has not been systematically examined.

\section{Exogenous markers used for single-injection clearance measures: diethylene triamine penta-acetic acid, ethylene diamine tetra-acetic acid, and iothalamate}

Historically, the plasma disappearance curve was most often used when GFR was assessed with radionuclides (Table 2). Even with single-injection techniques, radioactive markers are best avoided in small children. Diethylene triamine penta-acetic acid (DTPA) has a molecular mass of $393 \mathrm{Da}$ and is excreted primarily by glomerular filtration. GFR can be measured in each kidney with a scintillation camera and the ${ }^{98 \mathrm{~m}}$ Tc-DTPA complex; however, the correlation with $24 \mathrm{~h}$ creatinine clearances is only fair [56]. It should be noted that the plasma clearance of ${ }^{99 \mathrm{~m}} \mathrm{Tc}-$ DTPA significantly exceeds the urinary clearance $[57,58]$. On the other hand, the plasma clearance of ${ }^{99 \mathrm{~m}} \mathrm{Tc}-\mathrm{DTPA}$ correlates well with the renal clearance of inulin [58]. Failure to accurately measure GFR may reflect the fact that the ${ }^{99 \mathrm{~m}} \mathrm{Tc}$ can dissociate from the DTPA during the study, and there can be variations in protein binding depending on the ligand attached to DTPA [59]. Some preparations with ${ }^{99 \mathrm{~m}}$ Tc-DTPA gave results comparable to those with ${ }^{51} \mathrm{Cr}$ -
EDTA, while others underestimated GFR by 7-22\% [59]. Thus, the accuracy of ${ }^{99 \mathrm{~m}}$ Tc-DTPA may depend on the commercial source.

Estimation of GFR by use of radioisotopes is a commonly used technique in children, particularly with the limited availability of inulin and difficulties in collecting accurate timed urine in children. The most commonly used radioisotope is ${ }^{99 \mathrm{~m}} \mathrm{Tc}$-DTPA. One method calculates GFR from the uptake of labeled tracer in each kidney and allows determination of separate assessment of each kidney separately (split functions) [56]. A second method utilizes the disappearance of the labeled marker from the plasma, and, as noted above, DTPA is variably accurate as a marker of GFR.

Ethylene diamine tetra-acetic acid (EDTA) is another glomerular marker, with a molecular mass of $292 \mathrm{Da}$, and is used as a chelate of ${ }^{51} \mathrm{Cr}$, primarily in Europe. Its plasma clearance exceeds its urinary clearance by $\sim 6 \mathrm{ml} / \mathrm{min}$, particularly in patients with reduced renal function [58]. However, plasma clearance of ${ }^{51} \mathrm{Cr}$-EDTA agrees well with that of renal inulin clearance [58], indicating that it is a good marker for GFR. Values of ${ }^{51} \mathrm{Cr}$-EDTA plasma clearances increase from birth to age 18 months and, thereafter, they plateau. The absolute numbers agree well with measurements performed using inulin clearances.

Iothalamate sodium has a molecular mass of $636 \mathrm{Da}$. It has been used as ${ }^{125} \mathrm{I}$-radiolabeled or without radioactive label, its non-radioactive serum concentration being measured by X-ray fluorescence, high-performance liquid chromatography (HPLC), or by capillary electrophoresis. In a comparison of agents, the plasma clearance of ${ }^{125} \mathrm{I}$ iothalamate was $13 \%$ higher than that of ${ }^{51} \mathrm{Cr}$-EDTA [60]. The difference was reduced by pretreatment of the patients with probenecid, an organic anion secretory inhibitor. Extensive laboratory studies have shown unambiguously that iothalamate is actively secreted by renal proximal tubular cells and may also undergo some tubular reabsorption [60]. The renal clearance of iothalamate significantly exceeds that of inulin in patients with normal renal function 
Table 2 Properties of markers of glomerular filtration (M.M. molecular mass, Elim. elimination, $E C W$ extracellular water, $T B W$ total body water, EDTA ethylene diamine tetra-acetic acid. Data adapted from [72]

\begin{tabular}{lllllll}
\hline Property & Inulin & Creatinine & Iothalamate & DTPA & EDTA & Iohexol \\
\hline M.M. (Da) & 5,200 & 113 & 636 & 393 & 292 & 821 \\
Elim. half-life (min) & 70 & 200 & 120 & $<5$ & 110 & 120 \\
Protein binding (\%) & 0 & 0 & ECW & ECW & ECW \\
Space distribution & ECW & TBW & ECW \\
\hline
\end{tabular}

[61], and any reported agreement with inulin clearance may reflect a fortuitous cancellation of errors between tubular excretion and protein binding [62]. Another factor affecting comparability of inulin and iothalamate is the Gibbs Donnan distribution, enhancing anionic iothalamate clearance by about $5 \%$. Thus, iothalamate cannot be recommended as an ideal marker for measuring GFR.

\section{Iohexol}

A reliable alternative to inulin clearance avoids both the use of radioactivity and the problems related to timed urination and continuous infusion of the marker. Iohexol, a non-ionic, low osmolar, X-ray contrast medium (Omnipaque) that is safe and non-toxic and used in angiographic and urographic procedures, is eliminated from plasma exclusively by glomerular filtration [63]. Iohexol has a molecular mass of $821 \mathrm{Da}$, a plasma elimination half-time of $\sim 90 \mathrm{~min}$, is distributed into the extracellular space and has less than $2 \%$ plasma protein binding $[63,64]$. Iohexol is excreted completely unmetabolized in the urine, with $100 \%$ recovery within $24 \mathrm{~h}$ after injection [65]. Extrarenal elimination of iohexol in a setting of reduced GFR is negligible [66]. Since iohexol can be quantified in small samples, capillary, as well as venous, sampling can be employed [67]. A recent report by Niculescu-Duvaz et al. [68], suggests that, in the future, finger stick sampling, followed by automated HPLC analysis of blood spots collected on filter paper, may become a clinically viable option for measuring GFR with iohexol. Iohexol is measured in deproteinized plasma or serum by HPLC or $\mathrm{X}$-ray fluorescence.

The commercially available preparations contain two isomers of iohexol, both of which are handled similarly by the body [67, 69]. In practice, the major peak, eluting at about $5 \mathrm{~min}$, is used for determining serum/plasma concentrations [69]. Most studies indicate close agreement between GFR (measured by inulin clearance) and clearance of iohexol, measured as standard renal clearance or plasma disappearance $[65,69-72]$. There is not only a very good correlation between plasma iohexol clearance and that of ${ }^{51} \mathrm{Cr}$-EDTA, but also no difference between the methods by Bland-Altman analysis [73]. Direct comparison with iotha- lamate indicates that the iothalamate clearance exceeds that of iohexol by $19 \%$ [63].

Modeling of plasma disappearance of iohexol shows that its excretion conforms to a two-compartment open system $[65,69]$. In a pilot study for the National Institutes of Health (NIH)-supported Chronic Kidney Disease in Children (CKiD) study, we have found that, even with low GFR, serum iohexol concentrations decrease exponentially along the slow (renal) curve within 60-120 min of injection [30]. The clearance of iohexol (GFR) may also be calculated from the slow (renal) plasma disappearance curve (one-compartment system approximation beginning $120 \mathrm{~min}$ after injection) according to the method of Brochner-Mortenson (see above), [54] or by applying the Chantler correction, which assumes a constant correction factor of $0.87[74,75]$. In the CKiD GFR pilot study [30], calculation of the urinary clearance of iohexol was less precise than the plasma disappearance of iohexol, because of variability in the urine collections, with a median standard deviation between urine collection periods within an individual of approximately $24 \%$.

\section{Questions}

(Answers appear following the references.)

1. What is the most accurate method for determining GFR by plasma disappearance methods?
A) Iohexol
B) Iothalamate
C) Tc99-DTPA
D) Mannitol
E) Creatinine

2. When are estimate GFR formulae least accurate?
A) When subject is less than 10 years old
B) When subject is obese
C) When renal function is rapidly changing
D) When subject is volume contracted
E) When subject has recently used gentamicin

3. Which method is most useful for measuring GFR in children who may have underlying vesicoureteral reflux or bladder emptying problems?

A) MDRD estimate equation 
B) Classical renal inulin clearance

C) $24 \mathrm{~h}$ creatinine clearance

D) Nuclear renal imaging

E) Plasma disappearance

4. Cystatin $\mathrm{C}$

A) Acts as a cysteine proteinase promoter

B) Levels are substantially influenced by muscle mass and age

C) Is catabolized and almost completely reabsorbed by renal proximal tubular cells.

D) Is produced by breakdown of creatine

E) Can be used to measure GFR using standard urinary clearance measurement

5. Which of the following radionuclides is useful for GFR measurement?
A) ${ }^{99 \mathrm{~m}} \mathrm{Tc}-\mathrm{DTPA}$ (diethylene triamine penta-acetic acid)
B) ${ }^{125}$ I-Hippuran
C) ${ }^{99 \mathrm{~m}} \mathrm{Tc}-\mathrm{MAG}-3$ (mercapto-acetyl-triglycine)
D) ${ }^{99 \mathrm{~m}} \mathrm{Tc}$-dimercapto-succinic acid (DMSA)
E) ${ }^{131}$ I-meta-iodobenzyl-guanidine (MIBG)

Acknowledgement The CKiD is funded by the National Institute of Diabetes and Digestive and Kidney Diseases, with additional funding from the National Institute of Neurological Disorders and Stroke, the National Institute of Child Health and Human Development, and the National Heart, Lung, and Blood Institute (UO1-DK-66143, UO1DK-66174, UO1-DK-66116). The CKID website is located at http:// www.statepi.jhsph.edu/ckid. The clinical coordinating centers (Principal Investigators) are at Children's Mercy Hospital and the University of Missouri - Kansas City (Bradley Warady, MD) and Johns Hopkins School of Medicine (Susan Furth, MD, PhD), and the data coordinating center (Principal Investigator) is at the Johns Hopkins Bloomberg School of Public Health (Alvaro Munoz, PhD), with the Central Biochemistry Laboratory at the University of Rochester (George J. Schwartz, MD).

\section{References}

1. Smith HW (1951) The kidney. Structure and function in health and disease. Oxford University Press, New York, pp 492-519

2. McCance RA, Widdowson EM (1952) The correct physiological basis on which to compare infant and adult renal function. Lancet 2:860-862

3. Peters AM, Gordon I, Sixt R (1994) Normalization of glomerular filtration rate in children: body surface area, body weight or extracellular fluid volume? J Nucl Med 35:438-444

4. Kanwar YS, Venkatachalam MA (1992) Ultrastructure of glomerulus and juxtaglomerular apparatus, chap. 1. In: Windhager EE (ed) Handbook of physiology, section 8: Physiology vol 1. Oxford University Press, NY, pp 3-40

5. Hoy WE, Douglas-Denton RN, Hughson MD, Cass A, Johnson K, Bertram JF (2003) A stereological study of glomerular number and volume: preliminary findings in a multiracial study of kidneys at autopsy. Kidney Int Suppl 83:S31-S37
6. Hughson MD, Douglas-Denton R, Bertram JF, Hoy WE (2006) Hypertension, glomerular number, and birth weight in African Americans and white subjects in the southeastern United States. Kidney Int 69:671-678

7. Rose BD, Post TW (2001) Renal circulation and glomerular filtration rate, chap. 2. In: Wonsiewicz M, McCullough K, Davis $\mathrm{K}$ (eds) Clinical physiology of acid-base and electrolyte disorders, 5th edn. McGraw-Hill, NY, pp 21-70

8. Kanwar YS (1984) Biophysiology of glomerular filtration and proteinuria. Lab Invest 51:7-21

9. Addis T, Myers BA, Oliver J (1924) The regulation of renal activity. IX. The effect of unilateral nephrectomy on the function and structure of the remaining kidney. Arch Intern Med 34:243257

10. Dalton RN, Haycock GB (1999) Laboratory investigation, chap. 20. In: Barratt TM, Avner ED, Harmon WE (eds) Pediatric nephrology, 4th edn. Lippincott Williams \& Wilkins, Baltimore, pp 343-364

11. Arant BS Jr, Edelmann CM Jr, Spitzer A (1972) The congruence of creatinine and inulin clearances in children: Use of the Technicon autoanalyzer. J Pediatr 81:559-561

12. Cole BR, Giangiacomo J, Ingelfinger JR, Robson AM (1972) Measurement of renal function without urine collection. N Engl $\mathrm{J}$ Med 287:1109-1114

13. U.S. Renal Data System, USRDS 2002 Annual data report (2002) Atlas of end-stage renal disease in the United States. National Institutes of Health, National Institute of Diabetes and Digestive and Kidney Diseases, Bethesda, MD

14. Talbot NB (1938) Measurement of obesity by the creatinine coefficient. Am J Dis Child 55:42-50

15. Doolan PD, Alpen EL, Theil GB (1962) A clinical appraisal of the plasma concentration and endogenous clearance of creatinine. Am J Med 32:65-79

16. Schutte JE, Longhurst JC, Gaffney FA, Bastian BC, Blomqvist CG (1981) Total plasma creatinine: an accurate measure of total striated muscle mass. J Appl Physiol 51:762-766

17. Schwartz GJ, Gauthier B (1985) A simple estimate of glomerular filtration rate in adolescent boys. J Pediatr 106:522-526

18. Schwartz GJ, Feld LG, Langford DJ (1984) A simple estimate of glomerular filtration rate in full-term infants during the first year of life. J Pediatr 104:849-854

19. Hellerstein S, Berenbom M, Erwin P, Wilson N, DiMaggio S (2006) Timed-urine collections for renal clearance studies. Pediatr Nephrol 21:96-101

20. National Kidney Foundation. K/DOQI Clinical practice guidelines for chronic kidney disease: evaluation, classification, and stratification, part 5. Evaluation of laboratory measurements for clinical assessment of kidney disease guideline 4. Estimation of GFR. Website. 2002 6-23-2006, electronic citation

21. Greenblatt DJ, Ransil BJ, Harmatz JS, Smith TW, Duhme DW, Koch-Weser J (1976) Variability of 24-hour urinary creatinine excretion by normal subjects. J Clin Pharmacol 16:321-328

22. Richardson JA, Philbin PE (1971) The one-hour creatinine clearance rate in healthy men. JAMA 216:987-990

23. van Acker BAC, Koomen GCM, Koopman MG, de Waart DR, Arisz L (1992) Creatinine clearance during cimetidine administration for measurement of glomerular filtration rate. Lancet 340:1326-1329

24. Hellerstein S, Berenbom M, Alon US, Warady BA (1998) Creatinine clearance following cimetidine for estimation of glomerular filtration rate. Pediatr Nephrol 12:49-54

25. Hellerstein S, Erwin P, Warady BA (2003) The cimetidine protocol: a convenient, accurate, and inexpensive way to measure glomerular filtration rate. Pediatr Nephrol 18:71-72 
26. Schwartz GJ, Haycock GB, Edelmann CM Jr, Spitzer A (1976) A simple estimate of glomerular filtration rate in children derived from body length and plasma creatinine. Pediatrics $58: 259-263$

27. Schwartz GJ, Brion LP, Spitzer A (1987) The use of plasma creatinine concentration for estimating glomerular filtration rate in infants, children, and adolescents. Pediatr Clin North Am 34:571-590

28. Zappitelli M, Parvex P, Joseph L, Paradis G, Grey V, Lau S, Bell L (2006) Derivation and validation of cystatin C-based prediction equations for GFR in children. Am J Kidney Dis 48:221-230

29. Filler G, Priem F, Lepage N, Sinha P, Vollmer I, Clark H, Keely E, Matzinger M, Akbari A, Altaus H, Jung K (2002) $\beta$-Trace protein, cystatin $\mathrm{C}, \beta_{2}$-microglobulin, and creatinine compared for detecting impaired glomerular filtration rates in children. Clin Chem 48:729-736

30. Schwartz GJ, Furth S, Cole S, Warady B, Munoz A (2006) Glomerular filtration rate via plasma iohexol disappearance: Pilot study for chronic kidney disease in children. Kidney Int 69:2070-2077

31. Counahan R, Chantler C, Ghazali S, Kirkwood B, Rose F, Barratt TM (1976) Estimation of glomerular filtration rate from plasma creatinine concentration in children. Arch Dis Child 51:875-878

32. Fong J, Johnston S, Valentino T, Notterman D (1995) Length/ serum creatinine ratio does not predict measured creatinine clearance in critically ill children. Clin Pharmacol Ther 58:192-197

33. Cockcroft DW, Gault MH (1976) Prediction of creatinine clearance from serum creatinine. Nephron 16:31-41

34. Pierrat A, Gravier E, Saunders C, Caira MV, Ait-Djafer Z, Legras B, Mallie JP (2003) Predicting GFR in children and adults: a comparison of the Cockcroft-Gault, Schwartz, and Modification of Diet in Renal Disease formulas. Kidney Int 64:1425-1436

35. Finney H, Newman DJ, Thakkar H, Fell JM, Price CP (2000) Reference ranges for plasma cystatin $\mathrm{C}$ and creatinine measurements in premature infants, neonates, and older children. Arch Dis Child 82:71-75

36. Bökenkamp A, Domanetzki M, Zinck R, Schumann G, Brodehl J (1998) Reference values for cystatin C serum concentrations in children. Pediatr Nephrol 12:125-129

37. Grubb A (1992) Diagnostic value of analysis of cystatin C and protein HC in biological fluids. Clin Nephrol 38:S20-S27

38. Tenstad O, Roald AB, Grubb A, Aukland K (1996) Renal handling of radiolabelled human cystatin $\mathrm{C}$ in the rat. Scand $\mathrm{J}$ Clin Lab Invest 56:409-414

39. Keevil BG, Kilpatrick ES, Nichols SP, Maylor PW (1998) Biological variation of cystatin C: implications for the assessment of glomerular filtration rate. Clin Chem 44:1535-1539

40. Dworkin LD (2001) Serum cystatin C as a marker of glomerular filtration rate. Curr Opin Nephrol Hypertens 10:551-553

41. Coll E, Botey A, Alvarez L, Poch E, Quinto L, Saurina A, Vera M, Piera C, Darnell A (2000) Serum cystatin C as a new marker for noninvasive estimation of glomerular filtration rate and as a marker for early renal impairment. Am J Kidney Dis 36:29-34

42. Christensson A, Ekberg J, Grubb A, Ekberg H, Lindstrom V, Lilja $\mathrm{H}$ (2003) Serum cystatin C is a more sensitive and more accurate marker of glomerular filtration rate than enzymatic measurements of creatinine in renal transplantation. Nephron Physiol 94:19-27

43. Stickle D, Cole B, Hock K, Hruska KA, Scott MG (1998) Correlation of plasma concentrations of cystatin $\mathrm{C}$ and creatinine to inulin clearance in a pediatric population. Clin Chem 44:13341338

44. Filler G, Priem F, Vollmer I, Gellermann J, Jung K (1999) Diagnostic sensitivity of serum cystatin for impaired glomerular filtration rate. Pediatr Nephrol 13:501-505

45. Ylinen EA, Ala-Houhala M, Harmoinen APT, Knip M (1999) Cystatin $\mathrm{C}$ as a marker for glomerular filtration rate in pediatric patients. Pediatr Nephrol 13:506-509
46. Laterza OF, Price CP, Scott MG (2002) Cystatin C: an improved estimator of glomerular filtration rate? Clin Chem 48:699-707

47. Filler G, Lepage N (2003) Should the Schwartz formula for estimation of GFR be replaced by cystatin C formula? Pediatr Nephrol 18:981-985

48. Martini S, Prévot A, Mosig D, Werner D, van Melle G, Guignard JP (2003) Glomerular filtration rate: measure creatinine and height rather than cystatin $\mathrm{C}$ ! Acta Paediatr 92:1052-1057

49. Bökenkamp A, Domanetzki M, Zinck R, Schumann G, Byrd D, Brodehl J (1999) Cystatin C serum concentrations underestimate glomerular filtration rate in renal transplant recipients. Clin Chem 45:1866-1868

50. Knight EL, Verhave JC, Spiegelman D, Hillege HL, de Zeeuw D, Curhan GC, de Jong PE (2004) Factors influencing serum cystatin $\mathrm{C}$ levels other than renal function and the impact on renal function measurement. Kidney Int 65:1416-1421

51. Tkaczyk M, Nowicki M, Lukamowicz J (2004) Increased cystatin C concentration in urine of nephrotic children. Pediatr Nephrol 19:1278-1280

52. Uchida K, Gotoh A (2002) Measurement of cystatin-C and creatinine in urine. Clin Chim Acta 323:121-128

53. Sapirstein LA, Vidt DG, Mandel MJ, Hanusek G (1955) Volumes of distribution and clearances of intravenously injected creatinine in the dog. Am J Physiol 181:330-336

54. Brochner-Mortensen J (1972) A simple method for the determination of glomerular filtration rate. Scand J Clin Lab Invest 30:271-274

55. Brochner-Mortensen J, Haahr J, Christoffersen J (1974) A simple method for accurate assessment of the glomerular filtration rate in children. Scand J Clin Lab Invest 33:139-143

56. Piepsz A, Denis R, Ham HR, Dobbeleir A, Schulman C, Erbsmann F (1978) A simple method for measuring separate glomerular filtration rate using a single injection of ${ }^{99 \mathrm{~m}} \mathrm{Tc}-\mathrm{DTPA}$ and the scintillation camera. J Pediatr 93:769-774

57. LaFrance ND, Drew HH, Walser M (1988) Radioisotopic measurement of glomerular filtration rate in severe chronic renal failure. J Nucl Med 29:1927-1930

58. Rehling M, Moller ML, Thamdrup B, Lund JO, Trap-Jensen J (1984) Simultaneous measurement of renal clearance and plasma clearance of ${ }^{99 \mathrm{~m}} \mathrm{Tc}$-labelled diethylenetriaminepenta-acetate, ${ }^{51} \mathrm{Cr}$ labelled ethylenediaminetetra-acetate and inulin in man. Clin Sci 66:613-619

59. Carlsen JE, Moller ML, Lund JO, Trap-Jensen J (1980) Comparison of four commercial Tc-99m(Sn)DTPA preparations used for the measurement of glomerular filtration rate: concise communication. J Nucl Med 21:126-129

60. Odlind B, Hällgren R, Sohtell M, Lindström B (1985) Is ${ }^{125} \mathrm{I}$ iothalamate an ideal marker for glomerular filtration? Kidney Int 27:9-16

61. Perrone RD, Steinman TI, Beck GJ, Skibinski CI, Royal HD, Lawlor M, Hunsicker LG (1990) Utility of radioisotopic filtration markers in chronic renal insufficiency: simultaneous comparison of ${ }^{125}$ I-iothalamate, ${ }^{169} \mathrm{Yb}$-DTPA, ${ }^{99 \mathrm{~m}} \mathrm{Tc}-\mathrm{DTPA}$, and inulin. Am J Kidney Dis 16:224-235

62. Guignard J-P, Santos F (2004) Laboratory investigations, chap. 21. In: Avner ED, Harmon WE, Niaudet $P$ (eds) Pediatric nephrology, 5th edn. Lippincott Williams \& Wilkins, Philadelphia, pp 399-424

63. Back SE, Krutzen E, Nilsson-Ehle P (1988) Contrast media as markers for glomerular filtration: a pharmacokinetic comparison of four agents. Scand J Clin Lab Invest 48:247-253

64. Krutzen E, Back SE, Nilsson-Ehle I, Nilsson-Ehle P (1984) Plasma clearance of a new contrast agent, iohexol: a method for the assessment of glomerular filtration rate. J Lab Clin Med 104:955-961 
65. Olsson B, Aulie A, Sveen K, Andrew E (1983) Human pharmacokinetics of iohexol: a new nonionic contrast medium. Invest Radiol 18:177-182

66. Nilsson-Ehle P, Grubb A (1994) New markers for the determination of GFR: Iohexol clearance and cystatin $\mathrm{C}$ serum concentration. Kidney Int 46:S-17-S-19

67. Krutzen E, Back SE, Nilsson-Ehle P (1990) Determination of glomerular filtration rate using iohexol clearance and capillary sampling. Scand J Clin Lab Invest 50:279-283

68. Niculescu-Duvaz I, D’Mello L, Maan Z, Barron JL, Newman DJ, Dockrell ME, Kwan JT (2006) Development of an outpatient finger-prick glomerular filtration rate procedure suitable for epidemiological studies. Kidney Int 69:1272-1275

69. Gaspari F, Perico N, Ruggenenti P, Mosconi L, Amuchastegui CS, Guerini E, Daina E, Remuzzi G (1995) Plasma clearance of nonradioactive iohexol as a measure of glomerular filtration rate. J Am Soc Nephrol 6:257-263

70. Brown SCW, O'Reilly PH (1991) Iohexol clearance for the determination of glomerular filtration rate in clinical practice: evidence for a new gold standard. J Urol 146:675-679

71. Erley CM, Bader BD, Berger ED, Vochazer A, Jorzik JJ, Dietz K, Risler T (2001) Plasma clearance of iodine contrast media as a measure of glomerular filtration rate in critically ill patients. Crit Care Med 29:1544-1550

72. Rahn KH, Heidenreich S, Bruckner D (1999) How to assess glomerular function and damage in humans. J Hypertens 17:309-317

73. Brändström E, Grzegorczyk A, Jacobsson L, Friberg P, Lindahl A, Aurell M (1998) GFR measurement with iohexol and ${ }^{51}$ Cr-EDTA. A comparison of the two favoured GFR markers in Europe. Nephrol Dial Transplant 13:1176-1182

74. Chantler C, Barratt TM (1972) Estimation of glomerular filtration rate from plasma clearance of 51-chromium edetic acid. Arch Dis Child 47:613-617

75. Fleming JS, Zivanovic MA, Blake GM, Burniston M, Cosgriff PS, British Nuclear Medicine Society (2004) Guidelines for the measurement of glomerular filtration rate using plasma sampling. Nucl Med Commun 25:759-769s

76. Brion LP, Fleischman AR, McCarton C, Schwartz GJ (1986) A simple estimate of glomerular filtration rate in low birth weight infants during the first year of life: noninvasive assessment of body composition and growth. J Pediatr 109:698-707

77. Guignard JP, Torrado A, Da Cunha O, Gautier E (1975) Glomerular filtration rate in the first three weeks of life. J Pediatr 87:268-272

78. Barnett HL, McNamara H, Shultz S, Tompsett R (1949) Renal clearances of sodium penicillin $\mathrm{G}$, procaine penicillin $\mathrm{G}$, and inulin in infants and children. Pediatrics 3:418-422

79. Barnett HL, Hare WK, McNamara H, Hare RS (1948) Influence of postnatal age on kidney function of premature infants. Proc Soc Exp Biol Med 69:55-57

80. Richmond JB, Kravitz H, Segar W, Waisman HA (1951) Renal clearance of endogenous phosphate in infants and children. Proc Soc Exp Biol Med 77:83-87

81. Broberger U (1973) Determination of glomerular filtration rate in the newborn. Comparison between results obtained by the single injection technique without collection of urine and the standard clearance technique. Acta Paediatr Scand 62:625-629

82. McCrory WW, Forman CW, McNamara H, Barnett HL (1952) Renal excretion of inorganic phosphate in newborn infants. J Clin Invest 31:357-366

83. Brodehl J, Gellissen K, Weber HP (1982) Postnatal development of tubular phosphate reabsorption. Clin Nephrol 17:163-171

84. Gibb DM, Dalton NR, Barratt MT (1989) Measurement of glomerular filtration rate in children with insulin-dependent diabetes mellitus. Clin Chim Acta 182:131-139

\section{Answers}

1. A

2. $\mathrm{C}$

3. E

4. C

5. A 